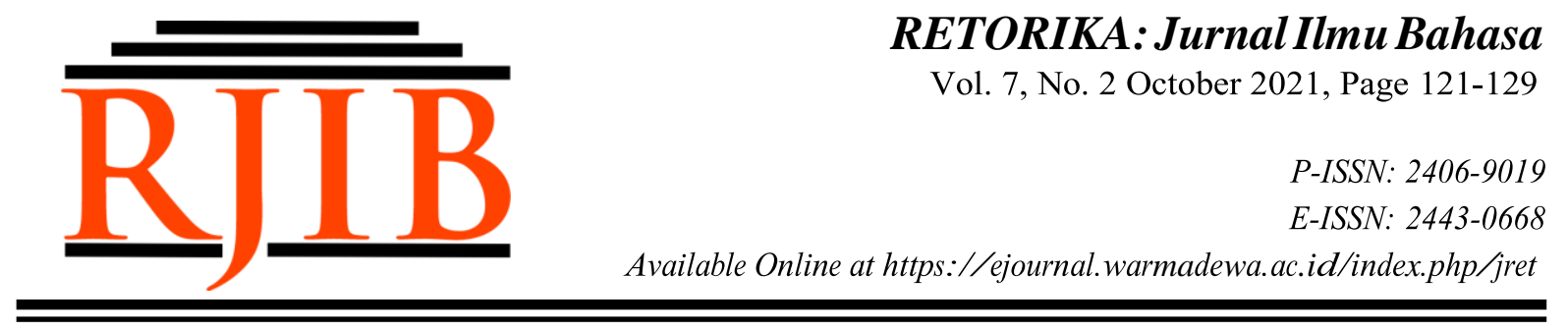

\title{
Codes Switching and Codes Mixing of Sellers and Buyers in Traditional Markets: Case Study of Market Kampong Asembagus Situbondo
}

\author{
${ }^{1}$ Muta'allim, ${ }^{2}$ Nawawi, ${ }^{3}$ Fahmi Reza Alfani, ${ }^{4}$ Abdul Azizul Ghaffar, ${ }^{5}$ Ali Wafi \\ ${ }^{1,5}$ Sekolah Tinggi Ilmu Tarbiyah Togo Ambarsari, ${ }^{2}$ Universitas Ibrahimy \\ 12alimhafidz@yahoo.com, ${ }^{2}$ nawawithabrani71@gmail.com \\ 3rezaalfanifahmi@gmail.com,yho.far35@gmail.com, ${ }^{5}$ aliwafi451@gmail.com
}

\begin{tabular}{|l|}
\hline Pow to cite (in APA style): \\
Muta'alim, Nawawi, Alfani, F. R., Ghaffar, A. A., \& Wafi, A. (2021). Codes Switching and Codes Mixing of Sellers and \\
Buyers in Traditional Markets: Case Study of Market Kampong Asembagus Situbondo. Retorika: Jurnal Ilmu \\
Bahasa, 7(2), 121-129. doi: https://doi.org/10.22225/jr.7.2.2627.121-129 \\
\hline
\end{tabular}

\begin{abstract}
The process of buying and selling communication in Asembagus Traditional Market often experiences language contact because the sellers and buyers come from several ethnicities who have different languages and cultures. This study aims to determine the form and the function of code-switching and codemixing speech between sellers and buyers in Asembagus Market, Situbondo. The method used in this study is a descriptive qualitative research. There are steps in data collecting technique; first, pay attention to and observe the data that has been collected based on the results of recordings and observations. Second, clasify their categories. Third, provide a table on the speech code switching and code mixing. Fourth, translating, describing and giving reasons for the code switching and interfering speech that occurred in the traditional market, namely Asembagus Situbondo Kampong market. The results showed that there were 12 forms of code switching speech and 10 code mixing speech between sellers and buyers at Asembagus Situbondo Market Kampong. They master more than one language and speakers try to build an atmosphere of speech with mixing languages.
\end{abstract}

Keywords: Code switching, Code mixing, Buy and sell speech, Traditional market

\section{INTRODUCTION}

The market is one of the places where people gather to carry out trading activities accompanied by communication interactions for a smooth buying and selling process. Kampong market is one of the traditional markets in Asembagus. It is said to be a market kampong because the market is located in a village area, namely in a village near the edge of the main road. The trading activity in Asembagus is carried out in the morning around 04.00 ( $\left.B a^{\prime} d a S u b u h\right)$, but in order to prepare goods to be sold, it is carried out in the afternoon, evening and before dawn.
Meanwhile, the end of the buying and selling interaction at the Kampong Market at around 06.00 WIB in the morning.

The sellers and buyers at the Kampong Market consist of several groups, namely traders, farmers, entrepreneurs, while the buyers consist of traders, farmers, entrepreneurs, teachers, employees, students and others. Today, the Asembagus community is a multilingual society because there are several ethnic groups who are not native Asembagus people who then settle and merge with the Asembagus community. It caused by several factors, including factors of cross- 
marriage, trade, immigration, overseas and so on. So, code switching and code mixing often occur the sellers and buyers are of different ethnicity and language.

Code switching is a situation where a speaker deliberately changes the code of the language in use for some reason. While code mixing is one of the utterances in which the seller or buyer inserts another language from the language used. People who often do crossmarriage, trade, immigration and overseas come from people of China, Java, Madura, Bali, Jakarta, Kangean and others. So that the languages spoken vary because they have different cultures and languages. Sellers and buyers often communicate in Indonesian, Madurese, Javanese and Kangean languages. So that sellers and buyers tend to mix and insert languages because of the context of the situation. To adjust to this context, it is necessary to choose the right language that is easy for sellers and buyers to understand when interacting.

In the process of buying and selling communication, there is often the use of the mother language, this is because the language is considered easy to understand by the Asembagus community. In general, sellers and buyers will always try to use language that is beautiful and easy to understand for both parties for the sake of smooth trading interactions. The smoothness of the interaction process depends on the language spoken, therefore it can be concluded that interacting through language that is easy to understand will make communication between sellers and buyers smooth. It is said so, because language functions as a conveyor of messages, ideas and thoughts. This was stated by Wardhaugh (1992) that the function of language is a means of human communication, both oral and written.

Kridalaksana (2008) language is a system of arbitrary sound symbols that are used by a community to cooperate, interact, and identify themselves. It is said to be arbitrary because language is arbitrary and belongs only to humans, this is what distinguishes the characteristics of humans from animals. Talking about language, we tend to humans. In essence, humans are social creatures that cannot be separated from language. However, language is arbitrary, it is said that because it varies from time to time. In other words, different tribes have different languages.

In Market, Kampong which consists of various different tribes, it will automatically tend to bring up the mother language even though Indonesian or other languages are used in interactions. The language (speech) that is often used by sellers and buyers in the market and code mixing. Code switching is one of the transitions of speech from one language to another. For example, sellers or buyers use Madurese when speaking and then switch to Javanese, Indonesian, English or other languages. For example, when a seller communicates using Madurese, but the buyer answers in Indonesian or other languages.

Meanwhile, code mixing is one of the utterances in which the seller or buyer inserts another language from the language used. For example, the seller said "this fish is very expensive because it's huge". Based on the example above, the original language used by the seller is Indonesian, but the seller inserts another word, namely the word "expensive". The word "expensive" is an English word which means "expensive". So the full meaning of the word is "this cakalan fish is very expensive because it is big".

There are several factors that tend to make sellers and buyers use code switching and mix speech codes in their interactions, including; sellers and buyers do not master the language, different ethnicities and different languages, there are foreign buyers, so that it is easily understood by sellers and buyers, there are limitations in mastering the language, for the smooth process of buying and selling interactions and to beautify the language.

There are several studies that are similar to the author's research. First, the research conducted by Purnamawati (2010) conduct research about mixing code and transferring the Speech of the Seller and the Buyer at Pasar Johar Semarang. The results of her research, shows that there are often people from other areas who produce speech forms so that each speaker is never loyal to one particular language or dialect. Therefore, the people in Johar market Semarang (sellers and buyers) are strived to uphold Indonesian as a unifying language.

Second, Wulandari, Marmanto, \& Sumarlan (2016) conducted research on Code 
Transfer in the dialogue of Asma Nadia's novel Heaven that was not missed. The results showed that the form of code switching is tag switching, intra-sentential code switching, and inter-sentential code switching through the use of declarative, imperative, and interrogative sentences. Marking Switching consists of 24 data, intra-sentential code switching consists of 12 data, and inter-sentential consists of 49 data.

Third, Mujiono (2013) conducted a research entitled Analysis of Code Transfer in English Language Teaching in the English Language Education Study Program at the University. The results of this research show that there are five forms of code switching in the form of language translation, namely code switching from English to Indonesian, Indonesian to English, English to Javanese, English to Arabic, Arabic to English. In this study also found types of code switching and their functions.

Fourth, the research conducted by Rohmani, Fuady, \& Anindyarini (2013). The results of the research shows that the symptoms of code switching are interwoven in four formations, while the factors of code switching are Extralinguistic and intralinguistic. Fifth, research conducted by Maryani (2011). The results of the research shows that there are regional language codes (Java) and foreign languages (Arabic and English) totalling 219 data. The most dominant code mixing found in the novel is the Arabic.

Based on studies that are similar to research conducted by researchers, similarities and differences have been found between previous studies and research conducted by researchers. The similarity of this research lies in the research subject, namely both researching code switching and code mixing. While the difference lies in the object of research, namely previous research examining code switching and code mixing contained in novels, teaching and learning activities in lectures and in the market. Meanwhile, the research conducted by the researcher was codeswitching and code-mixing speech between sellers and buyers that occurred in traditional markets, namely Kampong Asembagus Market, Situbondo.

There are several reasons that encourage researchers to conduct research entitled code switching and code mixing between sellers and buyers in the Traditional Kampong Market, they are (1) the phenomenon of code switching and code mixing is often occur in Kampong Market, ekspecially in Asembagus (2) the community is multiethnic and multilingual, so code switching and code mixing are often used by sellers and buyers to expedite the process of communication with transactions, communication and bargaining processes, (4) no researcher has yet conducted the research, and (5) there is an entertaint point to develop for produce the knowledge.

Based on the researchers above, there are differences with the researcher research althought the researches found by the researcher similarity. So, the researcher has oppurtinity to research the gap of the research. It makes the researcher is interested to done the research about the code mixing and the switching between the buyer and the seller in the traditional Market. Rahardi (2001) states that code is a kind of system used by two or more people to communicate. The code is divided into two, namely codes switching and codes mixing.

\section{LITERATURE REVIEW}

\section{Code Switching}

Code switching is one transitional utterances of the other languages. For example, sellers or buyers use Madurese when speaking and then switch to Javanese, Indonesian, English or other languages. For example, when a seller communicates using Madurese, but the buyer answers in Indonesian or other languages. According to Appel (1976), code switching is a symptom of a shift in language use due to changing situations. Hymes (1973) argues that code switching does not only occur between languages, but can also occur between varieties or styles that exist in one language.

Jendra (2001) explains that code switching is a situation where a speaker deliberately changes the language code that is being used for some reason. Poplack (2004) asserts that "code switching refers to the utterance-internal juxtaposition, in unintegrated form, of overt linguistic elements from two or more language, with no necessary change of interlocutor or topic". Translation "Code switching tends to be utterance, in the form of not being integrated, with language elements from two or more languages, with no change of 
speech partners or topics".

Furthermore, Muharram (2008) states that code switching is not a coincidence or an occurrence. arbitrarily, and it is not a disorder of language use as many people say, but is determined by various social and situational conditions and loaded with social meanings. Suwito (1985) divides code switching types; among them are internal code switching and code switching external.

\section{Code Mixing}

Basically, events or transitions that often occur between sellers and buyers in the village market are due to the interdependence of languages in communication. Code mixing is a speech in which the seller or buyer inserts another language from the language used. Chaer (2004) asserts that code mixing is a speech event where there are mixed phrases from other language phrases, each of which does not support its own function. Furthermore, Nababan (1984) states that code mixing is a language condition when people mix two (or more) languages or various languages in a speech act. This means that in a mixed speech the seller or buyer code inserts another language in the language used. For example, the seller said "ikan cakalan ini harganya sangat expensive karena besar-besar" (the cakalan fish is very expensive because it is big). Based on the example above, the original language used by the seller is Indonesian, but the seller inserts another word, namely the word "mahal (expensive)". The word "mahal" is an English word that used in the Indonesian communication. So, the communication called by code mixing.

However, Sumarsono (2004) emphasizes that words or sentences that have undergone an adaptation process in a language are no longer including words that experience interference symptoms, nor are they code switching, let alone mixed codes. It will be different if speakers consciously or deliberately use other language elements when speaking in a language. This event is then called code mixing. So, code-mixed speech is an insertion of another language from the language used or the use of two languages in deliberate or conscious speech.

Based on the above statement, it can be concluded that when communicating, sellers and buyers often insert code switching and code mixing is not a form of language error due to the speaker's weak mastery of the language used. It is said that because the speech of code switching and code mixing is done in a conscious or deliberate way. In this research, there are several forms of code mixing, including; word insertion, word group, clause insertion, and other phrase or idiom insertion.

\section{METHODS}

This research uses qualitative research. According to Salikin (2017) Qualitative research is a general term that shelters various kinds of philosophical orientations associated with interpretive terms. Often times, a qualitative study is called ethnographic research, case study, phenomenology, educational criticism or various other terms. Moleong (2000) states that qualitative research is a research procedure that produces descriptive data in the form of written or spoken words about certain characteristics.

Furthermore, Moleong (2000) asserts that descriptive research relies on data in the form of sentences, not numerical or statistical data, to describe the analysis. Strauss and Corbin (2007) state that qualitative research is a type of research whose findings are not obtained through statistical procedures or other forms of calculation. That is, qualitative research is research that does not take the form of a count, which discusses life, communication, stories, novels, poetry related to texts.

\section{Data Collection Techniques}

The data in this study is code switching and code mixing of sale and purchase speeches in the Asembagus Situbondo village market which are transcribed into written text. This research uses reduction data. According to Siswantoro (2010), the data reduction steps are as follows; first, prepare a data collection sheet; second, selecting data; third, describe the data; fourth, draw conclusions and fifth, verification.

Data is collected in several ways; First, prepare a data collection sheet. Second, selecting data, which means selecting codeswitching data and mixing code of buying and selling speech in the Kampong Asembagus Situbondo market. Third, describe the conversation data that has been selected and 
then give reasons. This has the aim of getting the accuracy of the data, to help or to make sure the writer determines the data related to code switching and speech code mixing.

Fourth, draw conclusions. This means checking the data that has been selected in order to obtain better accuracy. The accuracy of this research depends on the author himself. Fifth, prove the validity of the data. That is, the author in proving the data is adjusted to the results of recordings and observations.

\section{Data Analysis Techniques}

Siswantoro (2010) emphasizes that the data analysis is carried out by describing the descriptive form of each data functionally and relational. In addition, Siswantoro (2010) says that data is classified and explained based on concrete data. This means that in this study, the writer must analyze the data based on the results of recordings and observations.

These steps are as follows: first, pay attention to and observe the data that has been collected based on the results of recordings and observations. Second, to find the categories and differences in speech between code switching and code mixing in the Kampong Asembagus Situbondo market. Third, provide a table on the speech code switching and code mixing in the Asembagus Situbondo Kampong market based on the results of recordings and observations. Fourth, translating, describing and giving reasons for the code switching and interfering speech that occurred in the traditional market, namely the Asembagus Situbondo Kampong market.

\section{RESULS AND DISCUSSIONS}

Below the writer will describe the form of code switching and code mixing of buying and selling speech in traditional markets, namely Asembagus Situbondo village market. The speech is in the form of recordings which are transcribed into written text, then described in tabular form. After that, speech or sentences containing code switching and code mixing are analyzed. In this part, the author will discuss the forms of speech that contain code switching and code mixing in the traditional market, namely the Asembagus Situbondo market.

\section{The speech of buying and selling chicken fish}

Seller : ayo mbak, ini ikan ayamnya masih segar (come on, miss, this chicken fish is still fresh)

Buyer : ini ayam kampung atau ayam potong buk? (Is this chicken or chicken pieces, mom?)

Seller : ini ayam potong,areya ajem kampong, bak. (This is chicken and this is chicken pieces, miss).

Buyer : berempaan sakilu genika? (How the price of one kilogram?)

Seller : ajem ponapa se etanyae dika,ayam potong apa ayam kampong?(what chicken do you ask, chicken or chicken pieces?)

Buyer : ayam potong? (chicken pieces?)

Seller : satu kilo dua puluh lima ribu, ngobengana ajem ponapa dika? (the price is twenty five thousand one kilogram, which one do you want to buy?)

Buyer : mun ajem kampong sakilu berempa bu? (how about the price of chicken on one kilogram, mom?)

Seller : tello polo ebu. (thirty thounsands)

Buyer : behh,,,,mak larang? (behh,,,,,why its price is expensive?

Seller : iya, karena vitaminnya banyak. (because it contain many vitamins).

Buyer : ayam potong bheilah. (I buy the chicken pieces)

Seller : ok (oke).

Table 1. The speech of Buying and selling chicken fish

\begin{tabular}{|l|l|l|}
\hline \multicolumn{1}{|c|}{ Speeches } & \multicolumn{1}{|c|}{ Meaning } & \multicolumn{1}{|c|}{$\begin{array}{c}\text { Types of } \\
\text { speeches }\end{array}$} \\
\hline $\begin{array}{l}\text { Ini ayam potong, areya ajem } \\
\text { kampong, Bak. }\end{array}$ & $\begin{array}{l}\text { This is chicken and this is chicken } \\
\text { pieces, Miss. }\end{array}$ & Code mixing \\
\hline Berempaan sakilu genika? & (How the price of one kilogram?) & $\begin{array}{l}\text { Code } \\
\text { switching }\end{array}$ \\
\hline Ajem ponapa se etanyae dika,ayam & What chicken do you ask, chicken & Code mixing \\
\hline
\end{tabular}




\begin{tabular}{|l|l|l|}
\hline potong apa ayam kampong? & or chicken pieces? & \\
\hline $\begin{array}{l}\text { Satu kilo dua puluh lima ribu, } \\
\text { ngobengana ajem ponapa dika? }\end{array}$ & $\begin{array}{l}\text { The price is twenty five thousand } \\
\text { one one kilogram, which one do } \\
\text { you want to buy? }\end{array}$ & Code mixing \\
\hline $\begin{array}{l}\text { Mun ajem kampong sakilu berempa } \\
\text { bu? }\end{array}$ & $\begin{array}{l}\text { How about the price of chicken } \\
\text { on one kilogram, mom? }\end{array}$ & $\begin{array}{l}\text { Code } \\
\text { switching }\end{array}$ \\
\hline Tello polo ebu. & Thirty thounsands & $\begin{array}{l}\text { Code } \\
\text { switching }\end{array}$ \\
\hline Ayam potong bheilah & I buy the chicken pieces & Code mixing \\
\hline
\end{tabular}

In the speech of buying and selling chicken fish at the Asembagus kampong market, Situbondo, there are several stories of code switching and code mixing. Initially, the seller offered the chicken to the buyer in Indonesian and the buyer also responded in Indonesian as well. After that, suddenly the seller used "mixed code" by saying "ini ayam potong, areya ajem kampong, bak" This is done not because of an element of error, but an element of deliberation from the seller in order to make it easier for the buyer to interact because the seller knows that the buyer comes from Asembagus.

Then after the buyer hears the words of the seller using two languages (mixed code), the buyer responds also in another language, namely in Madurese by saying "berempaan sakilu genika?". After that, the seller continued to use two languages (mixed code) by saying "ajem ponapa se etanyae dika, ayam potong apa ayam kampong?", while the buyer changed the language again from Madura to Indonesian (code switching) by saying "chicken pieces". However, the seller continued to use two languages (mixed code), by saying "satu kilo dua puluh lima ribu, ngobengana ajem ponapa dika?" even though the buyer used it twice (code switching).

\section{Speeches of buying and selling the onion}

Buyer : bawang merahnya ada bak? (mis, is there a red onion?)

Seller : ada bak, mau beli berapa? (yes it is, how much do you want to buy?)

Buyer : sakilu saponapa gi? (How much the price on one kilogram?)

Seller : bebeng merah ponapa bebeng pote? (onion or garlic?)

Buyer : bebeng merah (onion)

Seller : tiga puluh lima ribu (thirty-five thousands)

Buyer : olle melle saparo-saparo gi? (can I buy a half on both?)

Seller : enggi boleh lah (of course)

Buyer : bawang pri ada juga bak? (is there onion pri, miss?)

Seller : bede jughen, berapa mau beli? (of course, how much do you want to buy?)

Buyer : bisa kalau beli dua polo ebu gi? (can I buy two thousands?)

Seller : enggi, boleh (of course)

Buyer : enggi pon (oke)

Table 2. The Speeches of buying and selling the onion

\begin{tabular}{|l|l|l|}
\hline \multicolumn{1}{|c|}{ Speeches } & \multicolumn{1}{|c|}{ Meaning } & \multicolumn{1}{c|}{$\begin{array}{l}\text { Types of } \\
\text { speeches }\end{array}$} \\
\hline $\begin{array}{l}\text { Sakilu saponapa } \\
\text { gi? }\end{array}$ & $\begin{array}{l}\text { How much the } \\
\text { price on one } \\
\text { kilogram? }\end{array}$ & $\begin{array}{l}\text { Code } \\
\text { switching }\end{array}$ \\
\hline $\begin{array}{l}\text { Bebeng merah } \\
\text { ponapa bebeng } \\
\text { pote? }\end{array}$ & Onion or garlic? & $\begin{array}{l}\text { Code } \\
\text { switching }\end{array}$ \\
\hline $\begin{array}{l}\text { Tiga puluh lima } \\
\text { ribu }\end{array}$ & $\begin{array}{l}\text { Thirty-five } \\
\text { thousands }\end{array}$ & $\begin{array}{l}\text { Code } \\
\text { switching }\end{array}$ \\
\hline $\begin{array}{l}\text { Olle melle } \\
\text { Can I buy a half }\end{array}$ & $\begin{array}{l}\text { Code } \\
\text { Cwitching }\end{array}$ \\
\hline
\end{tabular}




\begin{tabular}{|l|l|l|}
\hline Enggi boleh lah & of course & $\begin{array}{l}\text { Code } \\
\text { mixing }\end{array}$ \\
\hline $\begin{array}{l}\text { Bede jughen, } \\
\text { berapa mau beli? }\end{array}$ & $\begin{array}{l}\text { of course, how } \\
\text { much do you want } \\
\text { to buy? }\end{array}$ & $\begin{array}{l}\text { Code } \\
\text { mixing }\end{array}$ \\
\hline $\begin{array}{l}\text { Bisa kalau beli } \\
\text { dua polo ebu gi? }\end{array}$ & $\begin{array}{l}\text { can I buy two } \\
\text { thousands? }\end{array}$ & $\begin{array}{l}\text { Code } \\
\text { mixing }\end{array}$ \\
\hline Enggi, boleh & of course & $\begin{array}{l}\text { Code } \\
\text { mixing }\end{array}$ \\
\hline
\end{tabular}

In the speech and sale of onions in the Kampong Asembagus Situbondo market there are several code switching and code mixing. In the market, the buyer comes to the seller and asks in Indonesian, while the seller responds with the same language. After that, the buyer immediately switched to Madurese languages witching (code) by saying "sakilu saponapa ghi?" as well as the seller responded with the Madurese language also by saying "bebeng mera ponapa bebeng pote". This happens not because of technical errors in language, but sellers and buyers do it due to several factors such as, limited vocabulary, poor Indonesian language, to be easily understood between the two. After that, buyers and sellers suddenly changed from Madurese to Indonesian by saying "tiga puluh lima ribu". But then the buyer mixes or inserts Indonesian words that begin with Madurese. He said "Bisa kalau beli dua polo ebu gi?", but the seller uses both languages, namely Madurese and Indonesian (code switching).

\section{Speeches of buying and selling the eggplant}

Seller : nyare apa, Nak? (what are you looking for, Nak?)

Buyer : nyare terrong, $B u$ (I am looking for the eggplant, Mom)

Seller : nika terrong, mele pon, Nak (it is an eggplant, please choose it)

Buyer : saponapa nika mon beli satu kilo? (How much is the price on one Kilogram?)

Seller : lima ribu, nak. ngobengana saponapa dika? (five thousands, how much do you want to buy?)

Buyer : dua kilo aja, Bu, tapi kasih yang masih muda, Bu (only two kilos ma'am, but please give me a young aggplant ma'am)

Seller : enggi pon, eola'a gi? (oke, it will be cooked?)

Buyer : mau dibuat sayur di pondok (it want to make a vegetables in my islamic boarding school)

Seller : Pondok kaemma bekna cong, pondoknya Kyai Wildan ya? (where is your Islamic boarding school, is it in Kiyai Wildan's Islamic boarding school?

Buyer : enggi, Bu. (Yes, ma'am).

Seller : Oooooo. Ini saya kasih dua kilo lagi, Nak. (Oooooo. This is I give you two more kilograms)

Buyer : Enggi kasoon bu. (Thanks, Ma'am)

Seller : Iya nak sabhelekna. (you are welcome).

Tabel 3. Speeches of buying and selling the eggplant

\begin{tabular}{|c|c|c|}
\hline Speeches & Meaning & Types of \\
\hline 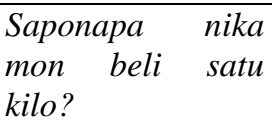 & $\begin{array}{l}\text { How much is the } \\
\text { price on one } \\
\text { Kilogram? }\end{array}$ & $\begin{array}{l}\text { Code } \\
\text { mixing }\end{array}$ \\
\hline $\begin{array}{l}\text { lima ribu, nak. } \\
\text { ggobengana }\end{array}$ & $\begin{array}{l}\text { five thousands, } \\
\text { how much do you }\end{array}$ & $\begin{array}{l}\text { Code } \\
\text { mixing }\end{array}$ \\
\hline
\end{tabular}




\begin{tabular}{|l|l|l|}
\hline saponapa dika? & want to buy? & \\
\hline $\begin{array}{l}\text { Dua kilo aja, Bu, } \\
\text { tapi kasih yang } \\
\text { masih muda, Bu }\end{array}$ & $\begin{array}{l}\text { only two kilos } \\
\text { ma'am, but } \\
\text { please give me a } \\
\text { young aggplant } \\
\text { ma'am }\end{array}$ & $\begin{array}{l}\text { Code } \\
\text { mixing }\end{array}$ \\
\hline $\begin{array}{l}\text { Enggi pon, eola'a } \\
\text { gi? }\end{array}$ & $\begin{array}{l}\text { oke, it will be } \\
\text { cooked? }\end{array}$ & $\begin{array}{l}\text { Code } \\
\text { switching }\end{array}$ \\
\hline $\begin{array}{l}\text { Mau dibuat sayur } \\
\text { di Pondok }\end{array}$ & $\begin{array}{l}\text { it want to make a } \\
\text { vegetables in my } \\
\text { islamic boarding } \\
\text { school }\end{array}$ & $\begin{array}{l}\text { Code } \\
\text { switching }\end{array}$ \\
\hline $\begin{array}{l}\text { Pondok kaemma } \\
\text { bekna cong, } \\
\text { pondoknya Kiyai } \\
\text { Wildan ya? }\end{array}$ & $\begin{array}{l}\text { where is your } \\
\text { Islamic boarding } \\
\text { school, is it in } \\
\text { Kiyai Wildan's } \\
\text { Islamic boarding } \\
\text { school? }\end{array}$ & $\begin{array}{l}\text { Code } \\
\text { mixing }\end{array}$ \\
\hline Enggi, Bu. & Yes, ma'am & $\begin{array}{l}\text { Code } \\
\text { mixing }\end{array}$ \\
\hline
\end{tabular}

In the eggplant sale speech there are several sentences and vocabulary that contain code switching and code mixing. First, the buyer (Santri) pacing around looking for vegetables, suddenly the seller asks in Madurese language by saying "nyare apa, Nak?" and the buyer responds to it also with the same language. After that, the buyer suddenly immediately changed the danger by mixing Indonesian with Madurese language by saying "saponapa nika mon beli satu kilo" (code switching). Similarly, the response of the seller balances the language of the buyer by saying "Lima ribu" (code switching).

This is done by sellers and buyers when communicating in the market Asembagus Situbondo not by accident. But buyers and sellers consciously or there is an element of intentionality when saying it. First, the buyer speaks Madurese because the seller is speaking Madurese for the first time. So, buyers here balance the language of the seller. Furthermore, the buyer suddenly switched to Indonesian because the buyer had a background in a hut that often speaks Indonesian. However, the seller also balances it with the aim of making the interaction process run smoothly.

\section{CONCLUSION}

The market is one of the places where people gather to carry out trading activities accompanied by communication interactions for a smooth buying and selling process.
Kampong market is one of the traditional markets in Asembagus. It is said to be a market kampong because the market is located in a village area, namely in a village near the edge of the main road.

In the Kampong Market, language switching and mixing of two languages often occur (code switching and code mixing) because the sellers and buyers are of different ethnicity and language. Code switching is a situation where a speaker deliberately changes the code of the language in use for some reason. While code mixing is one of the utterances in which the seller or buyer inserts another language from the language used.

Sellers and buyers switch languages (code switching) and mix languages (code mixing) when communicating not because they are unintentional, but they do it intentionally or consciously. In this study there are several factors that influence the occurrence of sellers and buyers who tend to switch languages (code switching) and language mixing (code mixing), such as; lack of vocabulary, creates humor, weak Indonesian language, so that it is easy to understand, balances the two and in order to smooth the process of buying and selling interactions. Based on the results of the above analysis, it can be seen that there are 12 codes mixing and 10 codes switching.

\section{REFERENCES}

Chaer, A., \& Agustina, L. (2004). Sociolinguistics 
Early Introduction. Jakarta: Jakarta Rineka Cipta.

Hymes, D. (1973). Foundations in Sociolinguistics: An Ethnographic Approach. Mt. Hood National Forest.

Jendra, M. (2001). Sociolinguistics. Yogyakarta: Graha Science.

Kridalaksana, H. (2008). Linguistic Dictionary. Jakarta: PT Gramedia Pustaka Utama.

Maryani, R. (2011). Analysis of Code Mixing in Novels When Love is Praised by Habiburrahman El Shirazy. Jakarta: Syarif Hidayatullah State Islamic University.

Moleong, L.J. (2000). Qualitative Research Methods. Bandung: PT Remaja Rosdakarya.

Muharram. (2008). Code Switching. http://muharrambanget.blogspot.com.

Mujiono. (2013). Analysis of Code Switching in Teaching English in the English Language Education Study Program at the University. Surakarta: Sebelas Maret University.

Nababan, P. W. J. (1984). Sociolinguistics. Jakarta: Gramedia Pustaka Umum.

Poplack, S. (1980). Sociolinguistics. An International handbook of the Science of Language and Society.

Purnamawati, A. (2010). Code Mixing and Code Switching for sellers and buyers at Pasar Johar Semarang. Semarang: IKIP PGRI Semarang.

Rahardi, K. (2001). Sociolinguistics. Yogyakarta: Student Library.

Rohmani, S., Fuady, A., \& Anindyarini, A. (2013). Analysis of Code switching and Code Mixing in Novel Negeri 5 Menara by Ahmad Fuadi. Journal of Language Research, 2 Number 1 .

Salikin, H. (2017). Researchers and Qualitative Research. Jakarta: RI National Library.

Siswantoro. (2010). Literary Research Methods. Yogyakarta: Student Library.

Sumarsono, \& P, P. (2004). Sociolinguistics. Yogyakarta: Sabda.

Suwito. (1985). Early Introductory Sociolinguistics. Surakarta: Henry offset.

Wardaugh, R. (1992). An Introduction to Sociolinguistics. Oxford: Basil Black Well.

Wulandari, R., Marmanto, S., \& Sumarlan. (2016). Code switching in Novel Heaven's Unmoved Dialogue by Asma Nadia. Journal of Linguistics, 1 Number 2. 